ISSN : $2302-1590$

E-ISSN: $2460-190 \mathrm{X}$

ECONOMICA

Journal of Economic and Economic Education Vol.2 No.2 (144 - 151)

\title{
PERBEDAAN HASIL BELAJAR EKONOMI DENGAN MENGGUNAKAN METODE KOOPERATIF JIGSAW DAN METODE KONVENSIONAL PADA SISWA KELAS $X$ SMA N 6 PADANG
}

\author{
Lena Mariza \\ Mahasiswa Program Studi Pendidikan Ekonomi STKIP- PGRI Sumbar \\ Jl. Gunung Pangilun No.1, Padang Sumatera Barat \\ Email: $\underline{\text { m4riza.lena@yahoo.com }}$ \\ Citra Ramayani \\ Dosen Program Studi Pendidikan Ekonomi STKIP- PGRI Sumbar \\ Jl. Gunung Pangilun No.1, Padang Sumatera Barat \\ Email: citra_berkatindo@yahoo.com \\ Submited: 2014.02.19 Reviewed: 2014.03.05 Accepted: 2014.04.12 \\ http://dx.doi.org/10.22202/economica.2014.v2.i2.227
}

\begin{abstract}
This study aims to analyze economic differences in learning outcomes of students who use the jigsaw method of cooperative learning with conventional learning method on economic subjects class X SMA Negeri 6 Padang. This research is a research experiment. Hypothesis test results obtained $Z_{\text {hitung }}$ was 3,508 while 1,960 $Z_{\text {tabel }}$ is that it looks bigger than $Z_{\text {tabel }} Z_{\text {hitung, means tested hypothesis }}(\mathrm{Ha})$ is accepted at the $5 \%$ significance level alfha so his decision is $H_{0}$ is rejected and Ha accepted so it can be concluded that there is a difference economic learning outcomes of students using cooperative learning jigsaw with the conventional method in class X SMA Negeri 6 Padang. From the results of this study are expected to teachers to implement jigsaw method of cooperative learning for material that is the theory. This jigsaw cooperative learning can improve student learning outcomes so that problems that occur in the learning process can be overcome
\end{abstract}

\begin{abstract}
Abstrak
Penelitian ini bertujuan untuk menganalisis perbedaan hasil belajar ekonomi siswa yang menggunakan metode pembelajaran kooperatif jigsaw dengan metode pembelajaran konvensional pada mata pelajaran ekonomi siswa kelas X SMA Negeri 6 Padang. Berdasarkan analisis data diketahui bahwa kedua kelas sampel berdistribusi normal dan homogen. Hasil uji hipotesis diperoleh $Z_{\text {hitung }}$ adalah 3,508 sedangkan $Z_{\text {tabel }}$ adalah 1,960 hal ini terlihat bahwa $Z_{\text {hitung }}$ lebih besar dari $Z_{\text {tabel }}$, berarti hipotesis yang diujikan $\left(H_{a}\right)$ diterima pada taraf nyata alfha $5 \%$ sehingga keputusanya adalah $H_{0}$ ditolak dan $H_{a}$ diterima sehingga dapat di simpulkan bahwa terdapat perbedaan hasil belajar ekonomi siswa menggunakan metode pembelajaran kooperatif jigsaw dengan metode konvensional di Kelas X SMA Negeri 6 Padang. Dari hasil penelitian ini diharapkan kepada guru untuk menerapkan Metode pembelajaran Kooperatif jigsaw untuk materi yang bersifat teori. Metode pembelajaran kooperatif jigsaw ini dapat meningkatkan hasil belajar siswa sehingga permasalahan yang terjadi dalam proses pembelajaran bisa diatasi.
\end{abstract}

Keywords: Learning Outcomes, jigsaw cooperative learning methods, conventional methods 
PENDAHULUAN

Sekolah sebagai lembaga formal pendidikan memegang peranan penting dalam meningkatkan kualitas pendidikan melalui pembelajaran untuk menunjang kelancaran jalannya pembangunan di indonesia secara keseluruhan. Pembelajaran merupakan kegiatan utama sekolah sebagai bentuk layanan pendidikan bagi masyarakat. Sekolah diberi kebebasan memilih strategi, metode, dan teknik pembelajaran sesuai dengan karakteristik mata pelajaran, siswa, guru, dan kondisi nyata sumber daya yang tersedia di sekolah. Secara umum, strategi/metode/teknik pembelajaran yang berpusat pada siswa (student centered) lebih mampu memberdayakan pembelajaran siswa.

Pendidikan menurut Kunandar (2007:6) adalah" investasi sumber daya manusia jangka panjang yang mempunyai nilai strategis bagi kelangsungan peradaban manusia di dunia". Oleh sebab itu, hampir semua Negara menempatkan variabel pendidikan sebagai sesuatu yang penting dan utama dalam konteks pembangunan bangsa dan negara. Begitu juga Indonesia menempatkan pendidikan sebagai sesuatu yang penting dan utama. Hal ini dapat dilihat pada Undang-Undang RI No.20 Tahun 2003, sistem pendidikan nasional adalah usaha sadar dan terencana, untuk mewujudkan suasana belajar dan proses pembelajaran.
Kemampuan siswa dalam belajar adalah kecakapan peserta didik, yang dimiliki dari apa yang telah dipelajari yang dapat dilihat atau ditunjukan dari hasil belajar. Rendahnya hasil belajar siswa juga dipengaruhi berbagai komponen, diantaranya guru dianggap sebagai faktor penyebab paling berpengaruh terhadap ketidak barhasilan belajar.

Berdasarkan observasi yang penulis lakukan pada tanggal 12 Agustus 2013 di kelas X SMA N 6 Padang pada semester I tahun ajaran 2013/2014, penulis melihat secara langsung proses pembelajaran yang dilaksanakan oleh guru bersangkutan, dengan langkah-langkah kegiatan sebagai berikut : guru menjelaskan materi pelajaran di depan kelas dengan menggunakan metode ceramah, kemudian siswa yang lain mencatat penjelasan guru tersebut. Setelah menjelaskan materi pembelajaran. Guru melakukan tanya jawab untuk menguji pemahaman siswa terhadap materi yang telah diajarkan. Akan tetapi hanya sedikit siswa yang mau bertanya, sedangkan siswa yang lain diam saja. Pada akhir pembelajaran guru memberikan tes untuk nilai hasil belajar siswa. ternyata hasilnya siswa masih banyak yang tidak tuntas. Hal ini dapat dilihat dari hasil belajar siswa berikut ini :

Tabel 1.Perolehan Hasil belajar rata-rata Ulangan Harian 1 Semester 1 Mata pelajaran Ekonomi Siswa Kelas X SMA N 6 Padang tahun ajaran 2013/2014

\begin{tabular}{ccccccc}
\hline Kelas & Jumlah & \multicolumn{2}{c}{ Tuntas } & \multicolumn{2}{c}{ Tidak Tuntas } & Nilai rata-rata kelas \\
\cline { 3 - 5 } & siswa & Jumlah & $\%$ & Jumlah & $\%$ & \\
\hline $\mathrm{X}_{1}$ & 32 & 22 & 68,8 & 10 & 31,2 & 77,07 \\
$\mathrm{X}_{2}$ & 32 & 24 & 75.0 & 8 & 25,0 & 77,25 \\
$\mathrm{X}_{3}$ & 32 & 20 & 62,5 & 12 & 37,5 & 72,25 \\
$\mathrm{X}_{4}$ & 32 & 10 & 31,3 & 22 & 68,7 & 56,78 \\
$\mathrm{X}_{5}$ & 32 & 9 & 28,3 & 23 & 71,7 & 56,55 \\
$\mathrm{X}_{6}$ & 33 & 19 & 57,6 & 14 & 42,4 & 69,28 \\
$\mathrm{X}_{7}$ & 33 & 19 & 57,6 & 14 & 42,4 & 69,09 \\
$\mathrm{X}_{8}$ & 32 & 16 & 50,0 & 16 & 50,0 & 66,53 \\
$\mathrm{X}_{9}$ & 33 & 18 & 54,6 & 15 & 45,4 & 65,28
\end{tabular}

Sumber : Buku nilai guru bidang studi ekonomi kelas X SMA N 6 Padang tahun ajaran 2013/2014 
Dari perolehan hasil belajar ulangan Harian I ekonomi kelas X SMA 6 Padang memilki rata-rata di bawah KKM (77), hanya kelas $\mathrm{X}_{1}$, dan $\mathrm{X}_{2}$ memilki nilai diatas KKM. Sedangkan kelas $\mathrm{X}_{3}, \mathrm{X}_{4}, \mathrm{X}_{5}, \mathrm{X}_{6}, \mathrm{X}_{7}$, $\mathrm{X}_{8}$, dan $\mathrm{X}_{9}$ masih di bawah rata-rata KKM.

Kurang maksimalnya hasil belajar siswa kelas X SMA N 6 Padang di sebabkan oleh beberapa faktor. Faktor yang mempengaruhi keberhasilan belajar dapat dibagi menjadi dua yaitu : faktor internal dan faktor eksternal. Faktor internal terdiri dari faktor biologis (jasmani) dan faktor psikologis, sedangkan faktor eksternal yaitu faktor lingkungan keluarga, masyarakat dan faktor lingkungan sekolah. Lingkungan sekolah sangat diperlukan untuk menentukan keberhasilan belajar siswa. Hal yang paling mempengaruhi keberhasilan belajar siswa disekolah mencakup metode mengajar, kurikulum, relasi guru dengan siswa, relasi siswa dengan siswa, pelajaran, waktu sekolah, tata tertib atau disiplin yang ditegakkan secara konsekuen dan konsisten.

Berdasarkan fenomena diatas, dituntut kemampuan guru yang lebih baik dalam proses pembelajaran di kelas, salah satunya adalah dengan menerapkan metode pembelajaran yang tepat terutama untuk pelajaran ekonomi. Metode pembelajaran yang diberikan guru juga sangat berpengaruh terhadap hasil belajar siswa. Mulyasa (2009: 63) menjelaskan bahawa "tugas guru yang paling utama adalah bagaimana mengkondisikan suasana belajar yang menyenangkan, agar dapat membangkitkan rasa ingin tahu semua peserta didik sehingga tumbuh minat nafsu untuk belajar". Pembelajaran yang menyenangkan dapat dilakukan secara individual dan kelompok.

Salah satu metode pembelajaran adalah pembelajaran kooperatif. Metode pembelajaran ini menekankan kepada siswa untuk saling bekerja sama dalam kelompoknya dimana setiap kelompok terdiri dari kemampuan akademik yang berbeda. Rusman(2012:202) yang menyatakan bahwa "Metode pembelajaran kooperatif adalah bentuk pembelajaran dengan cara siswa belajar dan bekerja dalam kelompokkelompok kecil secara kolaboratif yang anggotanya terdiri dari empat sampai enam orang dengan struktur kelompok yang bersifat heterogen".

Salah satu pendekatan pembelajaran kooperatif tipe pendekatan Struktur yang mengajar keterampilan sosial dalam berbagai kelompok adalah pembelajaran kooperatif jigsaw.Rusman (2012:218) menyatakan bahwa "pembelajaran kooperatif model jigsaw ini merupakan model belajar kooperatif dengan cara siswa belajar dalam kelompok kecil yang terdiri dari empat sampai enam orang secara heterogen dan siswa saling bekerja sama saling ketergantungan positif yang bertanggung jawab secara mandiri”. Beberapa alasan yang mendasari pembelajaran kooperatif metode jigsaw dipilih oleh penulis pada mata pelajaran ekonomi, pertama metode pembelajaran kooperatif jigsaw ini dapat digunakan dalam materi pelajaran ekonomi yang bersifat teori dan hitungan diharapakan dengan metode jigsaw ini akan membantu proses pembelajaran menjadi lebih menarik dan dapat memberi inovasi baru dalam pembelajaran. Sebelumnya pembelajaran terpusat pada guru saja (teacher centered), sehingga siswa bisa lebih aktif dan hasil belajar siswa akan meningkat. Kedua siswa bekerja sama dengan anggota kelompok yang heterogen yang akan memberikan peluang lebih besar untuk berinteraksi dan saling menerima, sehingga siswa memiliki keterampilan kerjasama yang baik. Ketiga siswa bertanggung jawab atas penguasaan materi yang ditugaskan kepadanya kemudian mengajarkan bagian tersebut kepada anggota lain dengan demikian siswa akan mudah mengigat materi pembelajaran. Keempat dengan penerapan metode jigsaw pembelajaran akan tidak hanya mengharapkan bantuan dari guru, akan tetapi siswa termotivasi untuk belajar, melatih keberanian siswa dalam mengemukakan pendapat, dan dapat membuat siswa tidak cepat menyerah dalam memahami dan mengerjakan soal-soal. Hal ini memungkinkan timbulnya semangat belajar lebih baik dibandingkan dengan pembelajaran konvensional. 


\section{Hasil belajar}

Hasil balajar merupakan tolak ukur yang digunakan untuk menentukan keberhasialan siswa dalam mengetahui dan memahami suatu konsep pembelajaran. Untuk mengetahui apakah siswa telah belajar dapat dilihat dari hasil belajar yang di peroleh setelah mengikuti proses belajar mengajar. Menurut Dimyati dan Mudjiono (2006:200) mengemukakan bahawa "hasil belajar adalah tingkat keberhasilan yang dicapai oleh siswa setelah mengikuti suatu pembelajaran dimana tingkat keberhasilan tersebut ditandai dengan skala nilai berupa huruf atau angka atau simbol".

\section{Metode Pembelajaran Kooperatif (Cooperative Learning)}

Metode pembelajaran kooperatif merupakan metode pembelajaran yang masih baru, yang dirancang untuk memberikan peluang kepada siswa untuk memperoleh pengalaman sehingga dapat mengembangkan tingkah lakunya sesuai sasaran belajar yang telah dirumuskan. Ciri pembelajaran kooperatif adalah siswa belajar dalam kelompok-kelompok kecil yang memiliki tingkat kemampuan berbeda, dalam menyelesaikan tugas kelompok setiap anggota kelompok saling bekerja sama dan membantu untuk memahami suatu materi pembelajaran.Rusman(2012:202) yang menyatakan bahwa"Metode pembelajaran kooperatif adalah bentuk pembelajaran dengan cara siswa belajar dan bekerja dalam kelompok-kelompok kecil secara kolaboratif yang anggotanya terdiri dari empat sampai enam orang dengan struktur kelompok yang bersifat heterogen".

Menurut Rusman mengemukakan beberapa variasi atau tipe pembelajaran kooperatif, namun prisip dasar dari pembelajaran kooperatif tersebut tidak berubah. Variansi model pembelajaran tersebut adalah :

\section{Student teams Achivement \\ Division ( STAD) \\ Dalam STAD siswa ditempatkan dalam tim-tim belajar beranggotakan empat sampai lima siswa yang heterogen.}

Adanya penghargaan kelompok dari hasil penilaian.

2. Jigsaw

Setiap anggota bertanggung jawab untuk mempelajari bagian tertentu atau yang ditugaskan sehingga muncul kelompok ahli

3. Grup Investigation ( GI )

Siswa bekerja dalam kelompok kecil untuk menangani berbagai macam proyek kelas

4. Make A Match (MembuatPasangan)

Siswa berpasangan dengan teman untuk mendiskusikan pertanyaan guru

5 Teams Games Tournaments (TGT)

Pertanyaan-pertanyaan yang ditulis pada kartu yang diberi angka.

\section{Metode Jigsaw}

Arti jigsaw dalam bahasa inggris adalah gergaji ukir dan ada juga yang menyebutnya dengan istilah puzzle yaitu sebuah teka-teki menyusun potongan gambar.Jigsaw telah dikembangkan dan di uji coba oleh Elliton Aroson dan temanteman dari Universitas Texsas USA. Pembelajaran kooperatif jigsaw ini mengambil pola cara bekerja sebuah gergaji (zigzag), yaitu siswa melakukan suatu kegiatan belajar dengan cara bekerja sama dengan siswa lain untuk mencapai tujuan bersama. Metode pembelajaran jigsaw adalah sebuah metode belajar kooperatif yang menitik beratkan pada kerja kelompok siswa dalam bentuk kelompok kecil.seperti yang di ungkapkan oleh Rusman (2012:218), bahwa " pembelajaran kooperatif model jigsaw ini merupakan model belajar kooperatif dengan cara siswa belajar dalam kelompok kecil yang terdiri dari empat sampai enam orang secara heterogen dan siswa saling bekerja sama saling ketergantungan positif yang bertanggung jawab secara mandiri”.

Menurut Priyanto dalam Wena (2011:194) dalam penerapan pembelajaran kooperatif modeljigsaw ada beberapa langkah yang harus dilaksanakan, yaitu sebagai berikut

1. Pembentukan kelompok asal 
Setiap kelompok asal terdiri dari 4-5 orang anggota dengan kemampuan yang heterogen

2. Pembelajaran pada Kelompok Asal Setiap anggota dari kelompok asal mempelajari submateri pelajaran yang akan menjadi keahliannya, kemudian masing-masing mengerjakan tugas secara individual

3. Pembentukan Kelompok Ahli

Ketua kelompok membagi tugas kepada masing-masing anggotanya untuk menjadi ahli dalam submateri pelajaran. Kemudian masing-masing ahli submateri yang sama dari kelompok yang berlainan bergabung membentuk kelompok baru yang di sebut kelompok ahli

4. Diskusi Kelompok Ahli

Anngota kelompok ahli mengerjakan tugas dan saling berdiskusi tentang masalah-masalah yang menjadi tanggung jawabnya.

5. Diskusi kelompok Asal (Induk )

Anggota kelompok ahli kembali ke kelompok asal masing-masing. Kemudian setiap anggota kelompok asal menjelaskan dan menjawab pertanyaan mengenai submateri pelajaran yang menjadi keahliannya kepada anggota kelompok asal yang lain. Ini berlangsung secara bergilir kepada anggota kelompok asal yang lain. Ini berlangsung secara bergilir sampai seluruh anggota kelompok asal telah mendapatkan giliran

6. Diskusi kelas

Dengan dipandu oleh guru diskusi kelas membicarakan konsep-konsep penting yang menjadi bahan perdebatan dalam diskusi kelompok ahli. Guru berusaha memperbaiki salah konsep pada siswa.

7. Pemberian kuis(latihan)

Kuis di kerjakan secra individu. Nilai yang diperoleh masing-masing anggota kelompok asal di jumlahkan untuk memperoleh jumlah nilai kelompok

8. Pemberian Penghargaan Kelompok

Kepada kelompok yang memperoleh juml;ah nilai tinggi diberikan penghargaan

\section{Metode pembelajaran konvensional}

Metode pembelajaran konvensional adalah metode pembelajaran klasik yang telah dipakai oleh tenaga pendidik sejak dulu dan masih sangat banyak ditemui pada saat ini. Metode pembelajaran yang berorientasi pada guru (teacher oriented) dimana hampir pembelajaran itu didomonasi oleh guru. Metode yang sering dipakai yaitu metode ceramah. Menurut pendapat Sagala (2003:201) bahwa metode ceramah adalah" suatu bentuk interaksi melalui penerangan dan penuturan lisan dari guru kepada peserta didik". Pembelajaran konvensional dalam penelitian ini dilakukan dengan cara menerangkan pelajaran di depan kelas, dilanjutkan dengan tanya jawab mengenai materi yang dipelajari, kemudian diberi contoh soal dan mengerjakan latihan.

\section{METODE PENELITIAN}

Penelitian ini tergolong kedalam Penelitian Eksperimen karena penulis melakukan treatmen atau perlakuan dan terencana. Arikunto (2010:9)menyatakan bahwa :"Penelitian eksperimen adalah suatu cara untuk mencari hubungan sebab akibat (hubungan kausal) antara dua faktor yang sengaja ditimbulkan oleh peneliti dengan mengeliminasi atau mengurangi atau menyisihkan faktor-faktor lain yang menganggu. Eksperimen selalu dilakukan denagn maksud untuk melihat akibat suatu perlakuan".Penelitian ini terdiri dari dua kelas sampel, yaitu kelas eksperimen dan kelas kontrol. Kelas eksperimen menggunakan metode pembelajaran kooperatif jigsaw, pada kelas kontrol yaitu menggunakan metode konvensional yang biasa dilakukan disekolah.

Untuk melihat hasil belajar Ekonomi siswa digunakan rancangan penelitian dengan menggunakan "Randomized Control Group Only Design". Rancangan ini digambarkan sebagai berikut 
Tabel 3. Rancangan Pelaksanaan Penelitian

\begin{tabular}{lcc}
\hline \multicolumn{1}{c}{ Kelas } & Perlakuan & Posttest \\
Eksperimen & $\mathrm{X}$ & $\mathrm{T}$ \\
Kontrol & - & $\mathrm{T}$ \\
\hline
\end{tabular}

Sumber : Suryabrata (2011:104)

Keterangan :

$\mathrm{X}$ : Perlakuan yang diberikan pada kelas eksperimen yaitu pembelajaran dengan metode jigsaw

T: Tes akhir yang akan diberikan pada kelas eksperimen dan kelas kontrol pada akhir pembelajaran

Penelitian ini dilakukan di SMA Negeri

6 Padang Jl. Sutan syahrirkelurahan Mata Air, Kecamatan Padang Selatan. Penelitian dilaksanakan pada semester 1 tahun ajaran 2013/2014, tepatnya bulan 26 Agustus sampai 19 September 2013. Populasi dalam penelitian ini adalah seluruh siswa kelas $\mathrm{X}$ SMA N 6 Padang tahun ajaran 201/2014 yaitu 291 siswa yang terdiri dari 9 kelas.

Sampel dalam Penelitian ini menggunakan teknik pengambilan sampel secara Purposive Sampling, dengan langkahlangkah sebagai berikut :

Tabel 5. Pembagian Kelas Sampel
1. Mengumpulkan nilai ulangan harian 1 siswa

2. Setelah rata-rata didapatkan dan lakukan pengambilan dua kelas nilai yang hampir sama

3. Untuk menentukan kelas eksperimen dan kelas kontrol dengan cara melihat hasil rata-rata ulangan harian 1 yaitu kelas yang paling rendah pertama rata-rata nilai ulangan 1 adalah kelas eksperimen dan kelas yang paling rendah kedua kelas kontrol.

\begin{tabular}{ccccc}
\hline No & Kelas & Jumlah Siswa & Rata -rata kelas & Perlakuan \\
\hline 1 & $\mathrm{X}_{4}$ & 32 & 56,78 & Kontrol \\
2 & $\mathrm{X}_{5}$ & 32 & 56,55 & Eksperimen \\
\hline
\end{tabular}

Sumber : buku nilai guru bidang studi ekonomi kelas X SMA N 6 Padang

Dalam penelitian ini data primernya yaitu data tentang hasil belajar Ekonomi yang berupa skor mentah hasil belajar siswa menggunakan metode pembelajaran kooperatif jigsaw dan metode pembelajran pembelajaran konvensional dan data sekunder penulis peroleh dari peroleh dari informasi pegawai tata usaha dan guru mata pelajaran Ekonomi SMA N 6 Padang berupa data hasilbelajar (nilai ulangan harian Ekonomi siswa pada kelas $\mathrm{X}$ semester I tahun ajaran 2013/2014), jumlahsiswa dan absensi.

Teknik pengumpulan data ini terdiri dari tigatahap yaitu tahap persiapan, tahap pelaksanaa, dan penyelesaiaan

1. Tahap Persiapan

Tahap peresiapan terdiri dari : a. Menetapkan jadwal dan waktu kegiatan

b. Mempersiapkan surat izin penelitian

c. Menyususn Rencana pelaksanaan Pembelajaran ( RPP)

d. Menbuat soal-soal kuis (latihan)

e. Mempersiapkan instrumen penelitian berupa soal akhir yang akan diberikan pada akhir pokok bahasan

2. Tahap Pelaksanaan

a. Materi pelajaran diberikan pada dua kelas berdasarkan kurikulum KTSP. Kedua kelas diberikan materi yang sama dengan metode pembelajaran yang berbeda

b. Proses belajar mengajar dilaksanakan dengan 4 kali pertemuan pada pertemuan terakhir dilakukan tes

Pembelajaran antara kelas eksperimen dan kelas kontrol berbeda. 
3.Tahap penyelesaian

Pada tahap akhir pada kelas eksperimen dan kelas kontrol diberikan tes hasil belajar dengan soal yang sama, sehingga dari hasilnya dapat dibandingkan hasil belajar antara kedua kelas sampel tersebut

Instrumen Penelitian dilakukan dengan langkah-langkah sebagai berikut :

a. Menyusun Tes

b. Uji Coba Tes

1. Validitas

2. Reliabilitas

3. Tingkat kesukaran soal

4. Daya pembeda

Teknik analisis data dalam penelitian ini dilakaukan dalam dua tahap yaitu analisis deskriptif dan analisis induktif. Analisis deskriptitif bertujuan untuk menggambarkan keadaan data apa adanya yang dikumpulkan dari sampel yang disajikan yaitu data dalam tabel distribusi frekuensi rata-rata, standar deviasi, koofesien variansi dan penentuan nilai minimum dan nilai maksimum.Analisis ini bertujuan ini untuk mengaitkan antara dua atau lebih variabel. Setelah diperoleh data penelitian berupa hasil belajar maka ditentukan rata-rata nilai ekonomi kelas eksperimen $\left(\mathrm{X}_{\mathrm{KE}-1}\right)$ dan rata-rata nilai ekonomi kelas kontrol $\left(\mathrm{X}_{\mathrm{KE}-2}\right)$. Jika $\mathrm{X}_{\mathrm{KE1}}>$ $\mathrm{X}_{\mathrm{KE} 2}$ dan perbedaan tersebut siginifikan maka diyakini perbedaan tersebut karena pengaruh dan perlakuan yang diberikan. Setelah itu dilakukan uji normalitas dan uji homogenitas terhadap kedua kelas sampel.

Teknik analisis data yang dimaksudkan untuk menguji hipotesis tentang perbedaan dua rata-rata. Apabila kedua kelas berasal dari populasi yang terdistribusi normal. Memilki varians yang homogen dan $r$ tidak diketahui. Dalam pengujian hipotesis statistik yang digunakan adalah uji Z .

\section{PEMBAHASAN}

Berdasarkan analisis data yang telah dilakukan terhadap hasil belajar ekonomi siswa menggunakan metode kooperatif Jigsaw dan metode ceramah (konvensional) di SMA Negeri 6 Padang terdapat perbedaan. Perbedaan ini dapat dilihat dari nilai tertinggi tes akhir kelas eksperimen 92 dengan rata-rata 81,31 sedangkan kelas kontrol nilai tertinggi 88 dengan nilai ratarata 72,87 sedangkan $\mathrm{Uji} Z \mathrm{Z}$ pada hasil belajar siswa diperoleh $Z_{\text {hitung }}$ 3,508 dan $Z_{\text {tabel }} 1.960$ pada taraf nyata 0,05 berdasarkan hasil perhitungan $\mathrm{Z}_{\text {hitung }}>\mathrm{Z}_{\text {tabel }}$ maka $\mathrm{H}_{0}$ ditolak. Dengan demikian dapat disimpulkan bahwa terdapat perbedaan yang signifikan antara hasil belajar siswa kelas eksperimen dengan hasil belajar siswa kelas kontrol yaitu kelas eksperimen menggunakan metode kooperatif jigsaw lebih tinggi dari pada hasil belajar siswa kelas kontrol yang menggunakan metode ceramah.

\section{PENUTUP}

Dari hasil penelitian yang telah dilakukan maka dapat di simpulkan bahwa hasil belajar siswa yang diajar dengan metode kooperatif jigsaw mata pelajaran Ekonomi pada materi konsep ekonomi dan kaitannya dengan kegiatan ekonomi produsen dan konsumen lebih baik dari pada menggunkan metode konvensional hal tersebut dapat dilihat dari perbedaan perbedaan dari nilai tertinggi tes akhir kelas eksperimen 92 dengan rata-rata 81,31 sedangkan kelas kontrol nilai tertinggi 88 dengan nilai rata-rata 72,87 sedangkan perhitungan sedangkan Uji $\mathrm{Z}$ pada hasil belajar siswa diperoleh $Z_{\text {hitung }} 3,508$ dan $Z_{\text {tabel }}$ 1.960 pada taraf nyata 0,05 berdasarkan hasil perhitungan $\mathrm{Z}_{\text {hitung }}>\mathrm{Z}_{\text {tabel }}$ maka $\mathrm{H}_{0}$ ditolak. Hal ini berarti bahwa hasil belajar ekonomi menggunakan metode kooperatif jigsaw lebih baik dari pada hasil belajar konvensional

Berdasarkan pada simpulan diatas, maka dapat dikemukakan beberapa saran yang bermanfaat untuk meningkatkan hasil belajar siswa, antara lain:

1. Agar guru-guru SMAN 6 Padang dapat menerapkan metode pembelajaran kooperatifjigsawsebagai salah satu alternatif metode pembelajaran yang dapat digunakan untuk meningkatkan hasil belajar siswa. 
2. Penerapan pembelajaran ini guru hendaknya dapat mengatur waktu dengan baik, sehingga tujuan pembelajaraan dapat tercapai secara maksimal.

3. Siswa diharapkan termotivasi belajar dengan menggunakan metode pembelajaran kooperatif jigsaw .

4. Kepada peneliti yang berminat disarankan untuk melakukan penelitian lanjutan pada materi yang berbeda.

\section{DAFTAR PUSTAKA}

10.22202/economica.2014.v2.i2.227

Anita, lie (2002). Cooperatif learning.PT.Gramedia : Jakarta .

Arikunto, Suharsimi. 2010. Prosedur Penelitian Suatu Pendekatan Praktik.

Rineka Cipta : Jakarta.

Aunurrahman. 2010. Belajar dan Pembelajaran. Alfabeta : bandung

Akhirmen . 2012. Statistik 1 (Teori dan Aplikasi). Padang: FE UNP.

Asma,Nur.2008. Model Pembelajaran Kooperatif.UNP Press: Padang .

Azizah,Nur. 2011 .Pengaruh Metode Pembelajaran Jigsaw Terhadap Hasil Belajar Mata Pelajaran Dasar Kompetensi Kejuruan Di SMK Wongsorejo Gomban .http:www.slideshare.net. 20 juni 2013 jam19.30.

Dimyati dan Mudjiono. 2006. Belajar dan Pembelajaran. Rineka Cipta: Jakarta

Hamalik. Oemar. 2009. Proses Belajar Mengajar. Bumi Aksara : Jakarta. 2005. kurikulum dan Pembelajaran.Bumi Aksara: jakarta.

Idris. 2008. Aplikasi Model Analisis Data Kuantitatif Dengan Program SPSS. Padang: FE UNP.

Kunandar. 2007, Guru Profesional. PT. Raja Grafindo Persada: Jakarta

Mulyasa. 2009. Implementasi Kurikulum Tingkat Satuan Pendidikan.Bumi Aksara : Jakarta
Nasution. 2001. Berbagai Pendekatan Dalam Proses Belajar Mengajar. Bumi Aksara : Jakarta.

Norlely,Nurul Rifki. 2011. Perbedaan Hasil Belajar Siswa Dengan Menggunakan Metode Kooperatif Jigsaw Dan Metode Konvensional Pada Mata Pelajaran TIK Kelas X Di SMA Negeri 5 Yogyakarta. http:www.slideshare.net. 20 juni 2013 jam19.35.

Rusman. 2012. Model -Model Pembelajaran.Rajawali : Jakarta

Samani, Muchlas dan Hariyanto.2011. Pendidikan Karakter. PT Remaja Rosdakarya: Bandung

Sagala,Syaipul. 2003. Konsep dan makna Pembelajaran. Alfabeta : Bandung.

Slameto. 2003. Belajar Dan Faktor-Faktor Yang Mempengaruhinya. Rineka Cipta : Jakarta

Sudjana, Nana. 2009. Penelitian Dan Penilaiaan Pendidikan. Sinar Baru Algesindo: Bandung

Sugiyono. 2004. Metode Penelitian Pendidikan.Alfabeta: Bandung

Sudijono,Anas.2011.Pengantar Evaluasi Pendidikan.

Rajagrafindo Persada:Jakarta.

Syaiful, Sgala. 2009. Konsep dan makna pembelajaran..Alfabeta: Bandung

Syah, Muhibin.2005. Psikologi Belajar. Raja Grafindo :Jakarta

Trianto. 2009. Mendesain Model-Model Pembelajaran Inovatif Progresif.Prenanda Media Group: Jakarta

Umar, Husein. 2011. Metode Penelitian Untuk Skripsi dan Tesis Bisnis. Jakarta: PT Raja Grafindo Persada.

Thoha. 2003. Teknik Evaluasi Pendidikan. Jakarta. PT. Raja Grafindo Persada

Wena, Made.2011.Strategi Pembelajaran Inovatif Kontemporer.Bumi Aksara; Jakarta

Yelmidawati.2009.Penerapan Pembelajaran Kooperatif Jigsaw Dalam Pembelajaran Matematika Siswa Kelas VIII SMP N I IV Jurai Pesisir Selatan. Skripsi: STKIP PGRI SUMBAR 
